\title{
Long-chain Omega-3 Polyunsaturated Fatty Acids in Natural Ecosystems and the Human Diet: Assumptions and Challenges
}

\author{
Michail I. Gladyshev ${ }^{1,2, *(1)}$ and Nadezhda N. Sushchik ${ }^{1,2}$ \\ 1 Institute of Biophysics of Siberian Branch of Russian Academy of Sciences, Akademgorodok, 50/50, \\ Krasnoyarsk 660036, Russia; labehe@ibp.ru \\ 2 Siberian Federal University, Svobodny av. 79, Krasnoyarsk 660041, Russia \\ * Correspondence: glad@ibp.ru
}

Received: 1 August 2019; Accepted: 7 September 2019; Published: 12 September 2019

\begin{abstract}
Over the past three decades, studies of essential biomolecules, long-chain polyunsaturated fatty acids of the omega-3 family (LC-PUFAs), namely eicosapentaenoic acid (20:5n-3, EPA) and docosahexaenoic acid (22:6n-3, DHA), have made considerable progress, resulting in several important assumptions. However, new data, which continue to appear, challenge these assumptions. Based on the current literature, an attempt is made to reconsider the following assumptions: 1 . There are algal classes of high and low nutritive quality. 2. EPA and DHA decrease with increasing eutrophication in aquatic ecosystems. 3. Animals need EPA and DHA. 4. Fish are the main food source of EPA and DHA for humans. 5. Culinary treatment decreases EPA and DHA in products. As demonstrated, some of the above assumptions need to be substantially specified and changed.
\end{abstract}

Keywords: eicosapentaenoic acid; docosahexaenoic acid; nutritive quality; eutrophication; fish; culinary treatments

\section{Introduction}

Polyunsaturated fatty acids in the omega-3 family (PUFAs) are a focus of interest in many fields of science: biochemistry, physiology, dietetics, pharmacology, agriculture, aquaculture, ecology, etc. [1-7]. For many animals and humans, long-chain polyunsaturated fatty acids (LC-PUFAs), namely eicosapentaenoic acid (20:5n-3, EPA) and docosahexaenoic acid (22:6n-3, DHA), are precursors of signaling molecules (bioactive lipid mediators) and essential components of cell membranes in neural and muscle tissues [8-11]. The number of publications on EPA and DHA in scientific journals has substantially increased since the 1970s (Figure 1). It is impossible to equally review LC-PUFA studies in all the fields of science; therefore, we will primarily take into consideration environmental issues, because natural and agricultural ecosystems are the source of EPA and DHA for human nutrition. There are many papers that report the fatty acid (FA) profiles of diverse microorganisms, plants, and animals, and address EPA and DHA as components of these profiles. However, we will consider only those studies that emphasize the role of these LC-PUFAs as well as their precursors.

In the field of ecology, even when studies have focused on primary producers (microalgae), the importance of EPA and DHA for human health was the rationale for the study of the content and composition of LC-PUFAs [12]. Indeed, only some taxa of microalgae can synthesize large amounts of EPA and DHA, while animals, including humans, have a comparatively low ability for such synthesis via conversion of the precursor, a short-chain PUFA, alpha-linolenic acid (18:3n-3, ALA) [13-15]. ALA, which is synthesized by plants, can be obtained by most animals only from food [16,17]. It should be noted that in contrast to EPA and DHA, which are synthesized by some algae, ALA is 
synthesized by terrestrial vascular plants and is the main component of the photosynthetic membranes of chloroplasts [18-21]. Since EPA and DHA can be efficiently synthesized de novo only by some taxa of algae, aquatic ecosystems are recognized as the main source of these LC-PUFAs in the biosphere [22]. The algae-synthesized EPA and DHA are transferred through trophic chains to organisms at higher trophic levels, invertebrates, and fish, and then to terrestrial consumers, including humans.

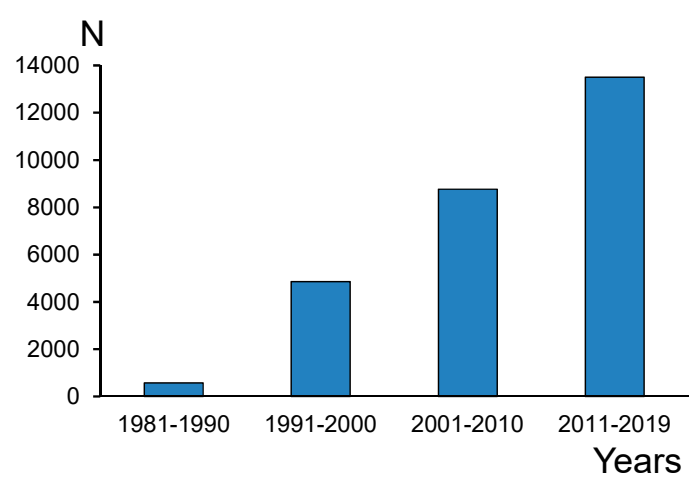

Figure 1. Number of publications containing $(N)$ the terms 'eicosapentaenoic' or 'docosahexaenoic' in the Web of Science Core Collection during the last four decades.

In studies of EPA and DHA transfer from microalgae to humans, which inevitably included the culinary treatment of aquatic products for human nutrition, considerable progress has been made in recent decades. Many important findings have been summarized in several keynote statements $[1,2,6,12,22]$, and a number of assumptions have appeared. New data appear continuously, and new questions arise, which naturally challenge some parts of the former assumptions. The aim of this paper is to consider and specify, if necessary, some important assumptions in the field of LC-PUFA production and regarding LC-PUFA transfer from natural ecosystems to the human diet.

\section{Assumption 1: There Are Algal Classes of High and Low Nutritive Quality}

In the nutrition ecology of zooplankton and other microalgaevorous organisms, microalgae have been subdivided into groups representing good and poor nutritive value according to their size and shape, and later to their carbon:nitrogen:phosphorus (C:N:P) ratio [23]. Starting with the milestone work of Ahlgren et al. [24], the PUFA content of microalgae became an important indicator of the nutritive quality of algae for consumers. In this work, it was found that Cryptophyceae and Dinophyceae (Peridinea) had high levels of EPA and DHA, and were the best food for zooplankton [24]. In turn, Chlorophyceae (green algae) and cyanobacteria contained no LC-PUFAs but certain levels of PUFAs, namely ALA, and had comparatively lower nutritive value [24]. Then, in another milestone paper, Muller-Navarra [25] demonstrated that Bacillariophyceae (diatoms), which had a high content of EPA, were a higher-quality food source for Daphnia than chlorophytes.

Since then, depending on their content of LC-PUFAs, microalgae have been subdivided into classes representing high and low nutritive quality, Cryptophyceae, Dinophyceae, and Bacillariophyceae vs. Chlorophyceae and cyanobacteria, respectively [26]. Some other classes of microalgae, Eustigmatophyceae, Prymnesiophyceae, Prasinophyceae, Chrysophyceae (golden algae), and Euglenophyceae, have also been shown to have a high content ( $\mathrm{mg} \mathrm{g}^{-1} \mathrm{C}$ ) of EPA and especially DHA [27-30]. Based on FA percentages, Trebouxiophyceae and Raphidophyceae were classified as intermediate and excellent food resources for zooplankton, respectively [31]. Recently, the division of phytoplankton classes into four categories was suggested based on the content of several biomolecules that included EPA and DHA: poor, medium, high, and superior quality food [30].

On the one hand, the division of microalgae into classes of high and low nutritive value in terms of their EPA and DHA content is reasonable. Indeed, Chlorophyceae and cyanobacteria (blue-green algae) do not produce these LC-PUFAs $[32,33]$. On the other hand, species from the classes lacking 
LC-PUFAs can have a high content of ALA, as mentioned above, and thereby provide a high growth rate for consumers that can efficiently convert ALA to EPA and DHA (e.g., [34-37] see also Assumption 3 below). For instance, there were no statistically significant differences among the growth rates of Daphnia magna when feeding on chlorophytes, chrysophytes, and diatoms [30]. The cited authors emphasized that the reproduction of D. magna in feeding experiments was dependent on total n-3 FAs rather than only on EPA.

Moreover, within algal classes that can synthesize EPA and/or DHA, there are species with low contents of these LC-PUFAs and thereby with low nutritive value. Indeed, EPA levels (as a percent of total FA) in 17 marine diatom species used in aquaculture ranged from 5 to 30\% [38]. The EPA content in diatoms per gram of organic carbon varied from $1.7 \mathrm{mg} \mathrm{g}^{-1} \mathrm{C}$ in Cyclotella meneghiniana [30] to $45.9 \mathrm{mg} \mathrm{g}^{-1} \mathrm{C}$ in Thalassiosira oceanica [39]. Moreover, in addition to inter-species variability, high variation in EPA content within one species occurs. Indeed, despite the lowest value for C. meneghiniana given above, a considerably higher content of EPA, $40.8 \mathrm{mg} \mathrm{g}^{-1} \mathrm{C}$, was reported for this species [25]. In natural ecosystems, it has been shown that some marine plankton diatoms have little EPA [40]. In a freshwater reservoir, Cyclotella was not associated with the EPA content in seston, while there was a significant correlation between Stephanodiscus and the content of EPA [41]. Similar results demonstrating contrasting levels of EPA in different diatom taxa were obtained for river littoral epilithic microalgae [42]. Evidently, diatom species can differ strongly in EPA content, and the common point of view that all diatoms are the superior quality food should be revised.

Consequently, dividing microalgae on the basis of their LC-PUFA content into classes appears to be too coarse for assessing nutritional value for consumers. It is worth noting that 'nutritional value' is not characteristic of a food item only, but indicates the demands of the consumer as well. Indeed, if a consumer does not need considerable amounts of EPA and DHA (see also Assumption 3 below), the above subdivision of microalgae into classes of high and low nutritive value is irrelevant. As found in a study of a freshwater plankton community, "there were no phytoplankton species of clearly high or low nutritive value. All phytoplankters, or at least detritus, that originated from them may meet the specific elemental and biochemical requirements of specific groups of zooplankton" [43]. Thus, Assumption 1 should be improved in future studies.

\section{Assumption 2: EPA and DHA Decrease with the Increasing Eutrophication of Aquatic Ecosystems}

The primary producers of EPA and DHA, Bacillariophyceae, Cryptophyceae and Dinophyceae are known to mainly inhabit oligotrophic aquatic ecosystems with low concentrations of total phosphorus (TP), while eutrophic (high TP) aquatic ecosystems are dominated by green algae and cyanobacteria, which do not produce LC-PUFAs (e.g., [44,45]). Thus, a high TP concentration decreases the contents of EPA and DHA in seston due to an increase of cyanobacteria, and thereby decreases the transfer of these LC-PUFAs to higher trophic levels [45,46]. Indeed, the EPA(DHA)-to-carbon content ratio in lake seston had a statistically significant negative relationship with TP concentration in lake water [46], and the EPA + DHA content in perch (per unit muscle mass) also had a statistically significant negative relationship with lake TP [45]. Thus, the nutritive quality of fish for humans becomes lower with eutrophication [45]. An increase in lake eutrophication, measured via the chlorophyll $a$ concentration, also resulted in a significant decrease in the EPA content in bighead carp [47].

However, in the above publications, the relative content of LC-PUFAs per unit of organic carbon, $\mathrm{C}$, or fish mass was estimated. These measures of relative content definitely indicate food quality, namely, the nutritive value of seston for zooplankton [46] and fish for humans [45,47]. In addition, if the quantification of the LC-PUFA supply for human nutrition is to be regarded as the paramount aim of relevant ecological studies, it is necessary to quantify this supply as the EPA and DHA yield, $\mathrm{Y}_{\text {LC-PUFA }}$ value, which has the units $\mu$ g or $\mathrm{mg}$ of LC-PUFA per $\mathrm{m}^{2}$ or $\mathrm{m}^{3}$ in an aquatic ecosystem per day or year. Thus, to convert food quality, i.e., the relative content of LC-PUFAs ( $\mu \mathrm{g} \mathrm{mg} \mathrm{C}^{-1}$ ), to the 
quantity, $\mathrm{Y}_{\mathrm{LC}-\mathrm{PUFA}}\left(\mu \mathrm{g} \mathrm{m}^{-3}\right.$ day $\left.^{-1}\right)$, it is necessary to take into account the production of organic carbon in an aquatic ecosystem, $\mathrm{V}\left(\mathrm{mg} \mathrm{C} \mathrm{m}^{-3}\right.$ day $\left.^{-1}\right)$ :

$$
\mathrm{Y}_{\mathrm{LC}-\mathrm{PUFA}}=\mathrm{LC}-\mathrm{PUFA} \cdot \mathrm{V}
$$

For instance, Muller-Navarra et al. [46] provided the following relation of the content of EPA $\left(\mu \mathrm{g} \mathrm{mg}^{-1} \mathrm{C}\right)$ in lake seston to the concentration of total phosphorus (TP; $\mu \mathrm{g} \mathrm{L}^{-1}$ ) in lake water:

$$
\ln \mathrm{EPA}=-0.69 \cdot \ln \mathrm{TP}+2.78 .
$$

From Equation (2), the following dependence can be obtained:

$$
\mathrm{EPA}=\mathrm{e}^{(-0.69 \cdot \ln \mathrm{TP}+2.78)}=16.12 \cdot \mathrm{TP}^{-0.69} .
$$

The dependence of the rate of photosynthesis (primary production), $\mathrm{V}\left(\mathrm{mg} \mathrm{C} \mathrm{m}^{-3}\right.$ day $\left.^{-1}\right)$, in lake phytoplankton on TP was given in [48]:

$$
\mathrm{V}=10.4 \cdot \mathrm{TP}-79
$$

To determine the value of the yield of EPA, $\mathrm{Y}_{\mathrm{EPA}}\left(\mu \mathrm{g} \mathrm{\textrm {m } ^ { - 3 }}\right.$ day $\left.^{-1}\right)$ (Equation (1)), i.e., its amount produced in a lake, it is necessary to multiply Equation (3) by Equation (4):

$$
\mathrm{Y}_{\mathrm{EPA}}=16.12 \cdot \mathrm{TP}^{-0.69} \cdot(10.4 \mathrm{TP}-79)=167.6 \cdot \mathrm{TP}^{0.31}-1273.5 \cdot \mathrm{TP}^{-0.69} .
$$

Graphs of Equations (3)-(5) are given in Figure 2. Evidently, with a decrease in the relative content of EPA in seston, there is an increase in EPA yield with increasing TP, i.e., with increasing lake eutrophication. The same is true for DHA if the analogue for Equation (1) is taken from Muller-Navarra et al. [46].

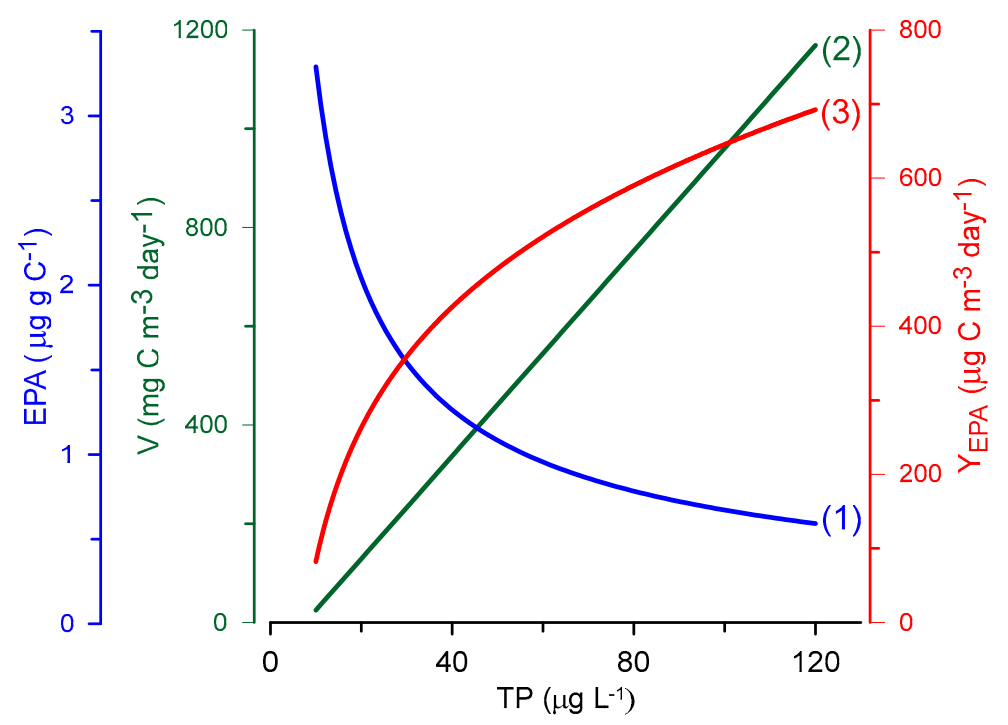

Figure 2. Dependence of the content of eicosapentaenoic acid in lake seston, EPA (1), rate of photosynthesis (primary production), $\mathrm{V}(2)$, and the yield of EPA, $\mathrm{Y}_{\mathrm{EPA}}(3)$, on the total phosphorus concentration in water, TP.

It is worth noting that according to Equation (4), the LC-PUFA yield produced by microalgae (lake phytoplankton) increases gradually with increasing TP (Figure 2). This relationship contradicts taxonomic changes in phytoplankton that usually occur during eutrophication. If primary production in a water body increases only at the expense of cyanobacterial or green algal growth, there would be 
no increase in LC-PUFA yield. In contrast, the EPA + DHA yield obtained from lakes where perch were caught increased up to a TP concentration of $\sim 40 \mu \mathrm{g} \mathrm{L}^{-1}$ and then decreased with increasing eutrophication [49]. Thus, the maximum LC-PUFA yield $\left(\mathrm{g} \mathrm{km}^{-2}\right.$ year $\left.{ }^{-1}\right)$ associated with fish catches occurred in mesotrophic rather than oligotrophic or eutrophic aquatic ecosystems [49].

Moreover, in eutrophic temperate lakes, cyanobacteria dominate in the phytoplankton community only in summer, while in spring, at low water temperatures, "blooms" of psychrophilic diatoms with high contents of EPA often occur. The above equation describing the relation between EPA and TP (Equation (2)) was obtained by Muller-Navarra et al. [46] for summer phytoplankton only. However, if a whole year is taken into consideration, in a eutrophic reservoir, a spring "bloom" of psychrophilic diatoms can produce a large pool of EPA, which can then be transferred through the trophic chain and peak in zooplankton and fish biomass with a time lag during summer [50]. It should also be noted that with decreasing phosphate availability, the proportion of EPA in some freshwater algae significantly decreased [51].

Thus, the common assumption that EPA and DHA decrease with increasing eutrophication of aquatic ecosystems should be improved. Such a decrease occurs in the relative contents of these LC-PUFAs per unit of sestonic organic carbon or fish biomass. However, with regard to EPA and DHA yield, including that available for human nutrition, measured as LC-PUFA quantity per unit area or volume of an aquatic ecosystem per unit time, such a decrease may not occur. At present, mesotrophic aquatic ecosystems are believed to provide a maximum supply of EPA + DHA for humans via fish catches. Ranking aquatic ecosystems on the basis of their ability to produce LC-PUFAs for human nutrition is an important challenge for future research.

\section{Assumption 3: Animals Need EPA and DHA}

As mentioned above, EPA and DHA play important biochemical and physiological roles in humans and many animals, and the common point of view is that all vertebrates and most invertebrate groups require these LC-PUFAs [52]. The low ability of animals to synthesize EPA and DHA from short-chain ALA necessitates them to obtain these LC-PUFAs from food. However, the commonly used terms of "many animals" and "most invertebrates" as well as "low ability" and "necessity" have not been specified or quantified yet. Furthermore, the hypothesis that in natural ecosystems "many" animals can be limited by a low EPA and DHA supply is the important premise of a number of studies [22,52]. Thus, the specification and quantification of the above terms seems to be an important challenge for relevant ecological studies [22,53].

First, it should be noted that a large group of invertebrates, terrestrial insects, practically do not have EPA and DHA [54-59]. Indeed, terrestrial insects use EPA only as the precursor of lipid mediators, eicosanoids, and thereby synthesize it from consumed ALA in small quantities, at the level of vitamins [60]. In contrast to terrestrial insects, aquatic (amphibiotic) insects have high levels of EPA in their biomass, but contain very low, if any, DHA [61-64]. As mentioned above, DHA is the main component of the phospholipids of the cell membranes of vertebrate neural tissues, including retinal photoreceptors $[3,4,65,66]$ (Figure 3). However, instead of DHA, there are 18C PUFAs in the eyes of terrestrial insects [3,67] (Figure 3), and EPAs in the eyes of amphibiotic insects [68] (Figure 3). Thus, terrestrial insects evidently do not need EPA or DHA, and aquatic insects do not need DHA in their food or in their biomass in considerable amounts.

Other terrestrial invertebrates, earthworms (Lumbricus terrestris), likely need EPA since they have a comparatively high content of this LC-PUFA in their biomass [69]. However, earthworms do not need to obtain these biomolecules from their food, since they likely obtain EPA from their gut microflora [69]. According to our unpublished data obtained using GC-MS and internal standards as in [61,70], Californian worms (Eisenia foetida) from a laboratory culture [71] contain $0.37 \pm 0.02$ and $0.02 \pm 0.02(n=3) \mathrm{mg} \mathrm{g}^{-1} \mathrm{WW}$ EPA and DHA, respectively. Moreover, some species of soil nematodes can de novo synthesize omega-3 PUFAs, namely ALA and EPA [72]. 
Herbivorous terrestrial vertebrates that consume green parts of plants can satisfy their physiological needs for EPA and DHA through the conversion of ALA [5,15,73]. Some omnivorous terrestrial vertebrates with high metabolic rates, such as the rattlesnake (Crotalus atrox), hummingbird (Archilochus colubris), white-throated sparrow (Zonotrichia albicollis), deer mouse (Peromyscus maniculatus), and bank vole (Myodes glareolus), have high proportions of DHA in their muscle phospholipids, accounting for up to 33\% of the total fatty acids [74-77]. However, these animals evidently have no dietary source of this LC-PUFA, because even aquatic insects or earthworms, if presented in the diet, could provide them with only EPA rather than DHA.

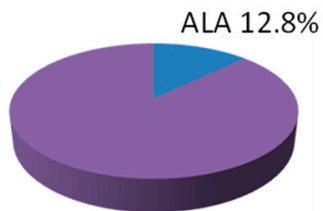

Drosophyla

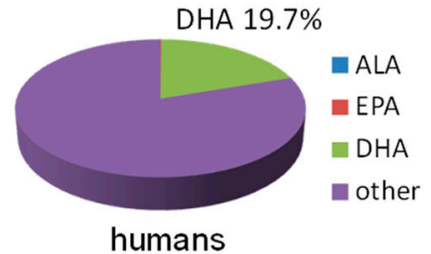

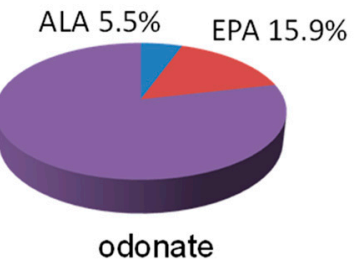

odonate

Figure 3. Levels (\% of total fatty acids) of alpha-linolenic (ALA), eicosapentaenoic (EPA) and docosahexaenoic (DHA) acids in the heads of Drosophila [67], the eyes of odonates [68] and human retinas [3].

The high levels of n-3 LC-PUFAs in the functional lipids and organs of some consumers, such as those mentioned above, certainly indicate the physiological significance of these compounds. Recently, new promising approaches have been used to confirm that a consumer has a dietary need for EPA and DHA. One of them combines the elucidation of a dietary source of LC-PUFAs for a consumer and possible physiological consequences of deprivation of this dietary source. For instance, wolf spiders (Tigrosa georgicola) that inhabited wetlands and consumed aquatic insects had higher tissue levels of aquatically derived LC-PUFAs and elevated immune function in comparison to upland spiders [78]. Another way to obtain evidence of a dietary need for EPA and DHA is to measure tissue LC-PUFA pools formed due to direct incorporation from an aquatic diet versus conversion from dietary ALA of terrestrial origin. For instance, Twining and colleagues [79] showed that the ALA content of terrestrial insects, and the ALA-to-EPA conversion efficiency, are insufficient to supply insectivorous tree swallow chicks with the n-3 LC-PUFAs that they require. The authors concluded that EPA-rich aquatic insects are ecologically essential resources during a critical ontogenetic period in this bird.

Thus, the statement that "many" animals need LC-PUFAs and must consume them can be challenged by the statement that "many" animals do not need EPA and DHA or do not need to obtain them from food. Evidently, more work is needed to specify species of aquatic and terrestrial animals that truly depend on dietary sources of LC-PUFAs.

\section{Assumption 4: Fish Are the Main Food Source of EPA and DHA for Humans}

Fish and aquatic invertebrates (shellfish, crayfish, etc.) are known to be the main source of LC-PUFAs for humans [7,80-84]. In general, i.e., on a global scale, this statement is absolutely true. However, in some cases, it should be used with caution. First, the contents of the sum of EPA + DHA in the edible parts (muscle tissue) of fish species varied $~ 400$-fold, from $32.78 \mathrm{mg} \mathrm{g}^{-1}$ wet weight (WW) in the boganid char (Salvelinus boganidae) [85] to $0.08 \mathrm{mg} \mathrm{g}^{-1} \mathrm{WW}$ in red hybrid tilapia (Oreochromis sp.) [86]. 
To obtain health benefits, the World Health Organization and some national nutrition and health organizations recommend daily personal consumption of $0.5-1.0 \mathrm{~g}$ of EPA + DHA $[6,7,81,87,88]$ and even $>1.0 \mathrm{~g}$ for a Western-type diet $[7,88]$. Thus, the recommended personal daily dose of EPA + DHA is contained in 15-30 g of meat of boganid char or in 6250-12500 g of meat of the tilapia. Naturally, a question arises: is the fish red hybrid tilapia a real source of LC-PUFAs for humans if 6-12 kg of its meat should be consumed daily to obtain the recommended healthy dose? If $1.0 \mathrm{~g}$ of EPA and DHA is considered as the daily dose for the reliable prevention of heart diseases and $1 \mathrm{~kg}$ as the maximum portion of fish per serving, the lower threshold value of EPA+DHA content in edible fish biomass is $1.0 \mathrm{mg} \mathrm{g}^{-1}$ [85]. All fish species with LC-PUFA contents below this threshold cannot be regarded as a "main source" of EPA and DHA for humans. Nevertheless, these "low LC-PUFA fish" are valuable sources of protein, vitamins, and other nutrients.

Second, some people do not eat fish, and so fish naturally cannot be the "main source" of EPA and DHA for them. For such people, there are alternative dietary LC-PUFA sources, for instance, the livers of terrestrial production animals, which contain EPA + DHA at a level close to the above threshold value of $1.0 \mathrm{mg} \mathrm{g}^{-1}$ [83]. However, as mentioned above, on a global scale, the livers of production animals, such as cattle, pigs, and chickens, cannot be alternatives to fish but represent an additional source only. Indeed, the global EPA + DHA supply through the wild fish catch is $\sim 18010^{6} \mathrm{~kg} \mathrm{year}^{-1}$, while the global production of both of these LC-PUFAs together in animal livers is $\sim 410^{6} \mathrm{~kg}$ year ${ }^{-1}$ [83]. In addition, some game birds from the order Passeriformes, which have EPA + DHA contents in their meat above the threshold value, from 1.8 to $3.7 \mathrm{mg} \mathrm{g}^{-1}$ [89], may also be an alternative source of these LC-PUFAs for humans who do not eat fish.

Human populations have different diets, e.g., the vegetarian diet in South and Eastern Asia and omnivorous (Western-type) diet in Europe and North America. As a rule, the LC-PUFA status of individuals from populations with a vegetarian diet, i.e., the content of EPA and DHA in various tissues and organs, is significantly lower than that of their omnivorous counterparts [90]. They commonly have a very low intake of preformed LC-PUFAs, ca. 10-74 mg per day, and most EPA and DHA is obtained as a result of the conversion of the dietary short-chain PUFA, ALA $[90,91]$. The following question arises: how does this conversion meet the demands for LC-PUFAs in vegetarian humans, since its rate is known to be low? Recent studies have found marked global polymorphism in the FADS (fatty acid desaturase) gene cluster, which is strongly associated with the efficiency of the conversion of linoleic and linolenic acids to LC-PUFAs of the corresponding family [92-94]. Human populations that have moved to more vegetarian diets are adapted to a low intake of LC-PUFAs, and these alleles provide the more efficient conversion of ALA to EPA and DHA. The selective patterns in FADS genes have been suggested to be driven by a change in the dietary composition of fatty acids following the transition to agriculture. Overall, there is a premise that vegetarian humans can function adequately with the found LC-PUFA status. More studies are necessary to assess the physiological and pathological outcomes of a vegetarian diet in terms of individual- and population-based genetic differences in the metabolism of dietary 18C-PUFAs [91,94].

When discussing fish as the main source of EPA and DHA for humans, the following paradox should be mentioned. Since the growing human population requires an increasing supply of essential LC-PUFAs, and wild catch fisheries are at exploitable limits, a greater proportion of food fish are obtained from aquaculture [95]. However, farmed fish, such as one of the most popular and valuable species, Atlantic salmon (Salmo salar), need high levels of EPA and DHA in their diet, which are obtained from the limited wild catch fisheries in fishmeal and fish oil [95]. Thus, in aquaculture oilseed, plant sources are increasingly used in feed to substitute the finite fishmeal and oil. This replacement of fish oil with the sustainable alternative, vegetable oils, has no detrimental effect on fish growth but results in a dramatic decrease in EPA and DHA in their flesh. For instance, the contents of EPA+DHA in the flesh of farmed Atlantic salmon in Scotland decreased from $27.4 \mathrm{mg} \mathrm{g}^{-1}$ in 2006 to $13.6 \mathrm{mg} \mathrm{g}^{-1}$ in 2015 [95]. Evidently, sustainable sources of EPA and DHA, in addition to fish, must inevitably satisfy the growing human population. 


\section{Assumption 5: Culinary Treatments Decrease EPA and DHA in Products}

Polyunsaturated fatty acids are known to be preferentially affected by oxidation during heating [96-98]. Thus, the degradation of LC-PUFAs in food during cooking and other culinary treatments has been reported by many authors [99-111]. However, other authors reported no decrease in EPA and DHA during cooking [70,83,112-123]. Indeed, products such as raw fish and production animals do not contain EPA and DHA in pure chemical form, but as components of phospholipids integrated into cell membranes, which have comparatively low susceptibility to degradation [82,124].

It is important to note that the above data on the degradation of LC-PUFAs during culinary treatments are based on measurements of their relative levels as a percentage of total FA. Furthermore, it has been demonstrated that the use of relative values (\%) instead of the absolute content of EPA and DHA ( $\mathrm{mg} \mathrm{g}^{-1} \mathrm{WW}$ ) for the estimation of nutritive value gives erroneous conclusions regarding the nutritive values of fish and other products for humans (e.g., [83,95,117,125-128]). For instance, there are many fish species with high EPA+DHA contents, $>8 \mathrm{mg} \mathrm{g}^{-1}$, but a low percentage, $<20 \%$, e.g., chum salmon (Oncorhynchus keta), coho salmon (Oncorhynchus kisutch), and lake trout (Salvelinus namaycush), while there are species with a high percentage, $>40 \%$, and low content, $<3 \mathrm{mg} \mathrm{g}^{-1}$, e.g., Atlantic cod (Gadus morhua) and whiting (Merlangius merlangus) [129].

Another striking example is related to edible macroalgae (seaweeds): red algae (Rhodophyta), (Palmaria palmata), have extremely high levels of EPA, ca. 50\% of the total fatty acids, but because of their very low total lipid contents, at realistic daily consumption levels, they cannot satisfy the LC-PUFA requirements of humans [126].

There is no correlation, or even a negative correlation, between EPA and DHA levels (\%) and contents $\left(\mathrm{mg} \mathrm{g}^{-1} \mathrm{WW}\right)$ in fish $[129,130]$. The explanation for the above phenomenon is believed to be as follows: EPA and DHA are mostly contained in phospholipids (PLs), i.e., in the structural lipids of cell membranes, which should remain nearly constant in proportion to functional muscle tissues, while many other fatty acids are contained in reserve neutral lipids, triacylglycerols (TAGs), whose composition is highly variable in fish biomass [125,130-132]. For this reason, in fish which are considered to be fatty, i.e., accumulating comparatively more TAG [133], EPA and DHA are "diluted", and their relative levels decrease.

Thus, the nutritive value of products for human nutrition should be estimated on the basis of the contents of EPA and DHA, mg per $\mathrm{g}$ of product, which can be obtained using internal standards during chromatography, rather than levels, or the $\%$ of total FAs $[83,117,127,134,135]$. Furthermore, content estimates based on internal standards are scarce, and most data are published as the level, or \%, of total FAs [100-102,105-111]. Here, we provide data obtained using internal standards, which allows us to compare the real nutritive value of fish and production animal products (Table 1). As noted in Assumption 4, some products prepared from terrestrial animals are comparable in their EPA and DHA contents with those of some fish (Table 1). In general, according to the quantitative data, mg per $\mathrm{g}$ of product, there is no decrease in LC-PUFA contents following most culinary treatments, and cooked products prepared from relevant raw biomass are good sources of EPA and DHA for humans. 
Table 1. Contents of the sum of eicosapentaenoic and docosahexaenoic fatty acids (EPA+DHA, $\mathrm{mg} \mathrm{g}^{-1}$ of product) in cooked fish and the daily portion of products (DP, g) that need to be consumed to obtain the recommended intake of EPA+DHA for humans, $1 \mathrm{~g}$ day $^{-1}$.

\begin{tabular}{|c|c|c|c|}
\hline Product & $\mathrm{EPA}+\mathrm{DHA}$ & DP & Reference \\
\hline Atlantic salmon Salmo salar (fried) & 40.1 & 25 & [121] \\
\hline Pacific saury Cololabis saira (canned, brand $\mathrm{H}$ ) & 37.9 & 26 & [136] \\
\hline Atlantic salmon Salmo salar (fried) & 19.6 & 51 & [114] \\
\hline Pacific herring Clupea harengus (canned) & 17.9 & 56 & [118] \\
\hline Atlantic salmon Salmo salar (fried) & 17.0 & 59 & [112] \\
\hline Baltic sprat Sprattus sprattus (canned) & 14.3 & 70 & [118] \\
\hline Pacific saury Cololabis saira (canned, brand N) & 13.1 & 76 & [136] \\
\hline King salmon Oncorhynchus tshawytscha (baked) & 12.4 & 81 & [137] \\
\hline Lake trout Salvelinus namaycush (baked) & 12.4 & 81 & [122] \\
\hline Lake trout Salvelinus namaycush (fried) & 12.4 & 81 & [122] \\
\hline Lake trout Salvelinus namaycush (broiled) & 12.3 & 81 & {$[122]$} \\
\hline King salmon Oncorhynchus tshawytscha (steamed) & 11.9 & 84 & [137] \\
\hline King salmon Oncorhynchus tshawytscha (fried) & 11.5 & 87 & [137] \\
\hline King salmon Oncorhynchus tshawytscha (microwaved) & 10.4 & 96 & [137] \\
\hline King salmon Oncorhynchus tshawytscha (poached) & 10.0 & 100 & [137] \\
\hline Sardine Sardina pilchardus (fried) & 8.8 & 114 & [112] \\
\hline Humpback salmon Oncorhynchus gorbuscha (boiled) & 6.0 & 167 & [116] \\
\hline Brown trout Salmo trutta (boiled) & 5.7 & 175 & {$[117]$} \\
\hline Humpback salmon Oncorhynchus gorbuscha (stewed) & 5.3 & 189 & [116] \\
\hline Humpback salmon Oncorhynchus gorbuscha (roasted) & 5.0 & 200 & [116] \\
\hline Humpback salmon Oncorhynchus gorbuscha (fried) & 4.3 & 233 & [116] \\
\hline Brown trout Salmo trutta (fried) & 4.1 & 244 & [117] \\
\hline Cod Gadus morhua (fried) & 4.1 & 244 & [114] \\
\hline Spanish mackerel Scomberomorus commerson (fried) & 3.9 & 256 & [112] \\
\hline Pacific herring Clupea harengus (boiled) & 3.9 & 256 & [117] \\
\hline Pacific herring Clupea harengus (fried) & 3.8 & 263 & [117] \\
\hline Rock sole Lepidopsetta bilineata (boiled) & 3.6 & 278 & [117] \\
\hline Chinook salmon Oncorhynchus tshawytscha (fried) & 3.2 & 313 & [122] \\
\hline Rock sole Lepidopsetta bilineata (fried) & 3.1 & 323 & [117] \\
\hline Chinook salmon Oncorhynchus tshawytscha (baked) & 3.1 & 323 & [122] \\
\hline White sucker Catostomus commersonii (baked) & 2.3 & 435 & [122] \\
\hline Cod Gadus morhua (boiled) & 2.4 & 417 & [117] \\
\hline Chinook salmon Oncorhynchus tshawytscha (fried) & 2.8 & 357 & [122] \\
\hline Cod Gadus morhua (fried) & 2.2 & 455 & [121] \\
\hline Walleye (Sander vitreus) (baked) & 2.1 & 476 & {$[122]$} \\
\hline White sucker Catostomus commersonii (broiled) & 2.1 & 476 & [122] \\
\hline White sucker Catostomus commersonii (fried) & 2.0 & 500 & [122] \\
\hline Walleye (Sander vitreus) (broiled) & 1.9 & 526 & [122] \\
\hline Walleye (Sander vitreus) (fried) & 1.9 & 526 & [122] \\
\hline Prawn Macrobrachium acanthurus (fried) & 1.8 & 556 & [138] \\
\hline Beef liver (boiled) & 1.3 & 769 & [83] \\
\hline Zander Sander lucioperca (boiled) & 1.1 & 909 & [70] \\
\hline Pork liver (boiled) & 1.0 & 1000 & [83] \\
\hline Zander Sander lucioperca (stewed) & 1.0 & 1000 & [70] \\
\hline Zander Sander lucioperca (fried) & 1.0 & 1000 & {$[70]$} \\
\hline Common carp Cyprinus carpio (fried) & 1.0 & 1000 & [122] \\
\hline Chicken liver (boiled) & 0.7 & 1429 & [83] \\
\hline Common carp Cyprinus carpio (baked) & 0.7 & 1429 & [122] \\
\hline Gilthead sea bream Sparus aurata (fried) & 0.6 & 1667 & [139] \\
\hline Common carp Cyprinus carpio (broiled) & 0.5 & 2000 & [122] \\
\hline Pork (fried) & 0.3 & 3333 & [119] \\
\hline White rabbit (baked) & 0.1 & 10000 & [140] \\
\hline
\end{tabular}




\section{Conclusions}

A number of assumptions important for developing LC-PUFA studies in the ecological and food sciences should be improved:

1. Dividing microalgae on the basis of their LC-PUFA content into classes of high and low nutritive value appeared to be too coarse. Although there are no Chlorophyceae (green algae) that contain EPA and DHA, there are Bacillariophyceae (diatoms) with low contents of LC-PUFAs.

2. The maximum LC-PUFA yield $\left(\mathrm{g} \mathrm{km}^{-2}\right.$ year $\left.{ }^{-1}\right)$ that can be ultimately obtained by humans occurs in mesotrophic rather than oligotrophic aquatic ecosystems.

3. Many animals and terrestrial insects do not need EPA, and aquatic insects do not need DHA in any considerable quantity. Many other animals do not need LC-PUFAs in their food: some worms can obtain these biomolecules from their intestine microflora, and strictly herbivorous terrestrial mammals can synthesize required quantities of EPA and DHA from ALA obtained from the green parts of consumed plants.

4. There are many fish species that are not adequate sources of EPA and DHA for humans, especially for those with a Western-type diet. In turn, there are products of terrestrial animals that can be a source of LC-PUFAs for persons who do not eat fish. In human populations with a vegetarian diet, the conversion of dietary C18-PUFAs is considered to be sufficient to meet the demands for LC-PUFAs based on the found genetic patterns; however, this statement requires further study.

5. Most common culinary treatments do not decrease the EPA and DHA contents in fish and other animal products.

Author Contributions: Conceptualization, calculations, writing-original draft preparation, M.I.G.; writing - review and editing, N.N.S.

Funding: This study was funded by the Russian Science Foundation, grant number 16-14-10001.

Acknowledgments: We are grateful to anonymous Reviewers for their valuable recommendations to improve the manuscript.

Conflicts of Interest: The authors declare no conflict of interest.

\section{References}

1. Simopoulos, A.P. Human requirement for n-3 polyunsaturated fatty acids. Poult. Sci. 2000, 79, 961-970. [CrossRef] [PubMed]

2. Arts, M.T.; Ackman, R.G.; Holub, B.J. “Essential fatty acids” in aquatic ecosystems: A crucial link between diet and human health and evolution. Can. J. Fish. Aquat. Sci. 2001, 58, 122-137. [CrossRef]

3. Lauritzen, L.; Hansen, H.S.; Jorgensen, M.H.; Michaelsen, K.F. The essentiality of long chain n-3 fatty acids in relation to development and function of the brain and retina. Prog. Lipid Res. 2001, 40, 1-94. [CrossRef]

4. SanGiovanni, J.P.; Chew, E.Y. The role of omega-3 long-chain polyunsaturated fatty acids in health and disease of the retina. Prog. Retin. Eye Res. 2005, 24, 87-138. [CrossRef] [PubMed]

5. Wood, J.D.; Enser, M.; Fisher, A.V.; Nute, G.R.; Sheard, P.R.; Richardson, R.I.; Hughes, S.I.; Whittington, F.M. Fat deposition, fatty acid composition and meat quality: A review. Meat Sci. 2008, 78, 343-358. [CrossRef]

6. Kris-Etherton, P.M.; Grieger, J.A.; Etherton, T.D. Dietary reference intakes for DHA and EPA. Prostaglandins Leukot. Essent. Fat. Acids 2009, 81, 99-104. [CrossRef]

7. Tocher, D.R.; Betancor, M.B.; Sprague, M.; Olsen, R.E.; Napier, J.A. Omega-3 long-chain polyunsaturated fatty acids, EPA and DHA: Bridging the gap between supply and demand. Nutrients 2019, 11, 89. [CrossRef]

8. Casula, M.; Soranna, D.; Catapano, A.L.; Corrao, G. Longterm effect of high dose omega-3 fatty acid supplementation for secondary prevention of cardiovascular outcomes: A meta-analysis of randomized, double blind, placebo controlled trials. Atheroscler. Suppl. 2013, 14, 243-251. [CrossRef]

9. Dyall, S.C. Long-chain omega-3 fatty acids and the brain: A review of the independent and shared effects of EPA, DPA and DHA. Front. Aging Neurosci. 2015, 7, 52. [CrossRef]

10. Weiser, M.J.; Butt, C.M.; Mohajeri, M.H. Docosahexaenoic acid and cognition throughout the lifespan. Nutrients 2016, 8, 99. [CrossRef] 
11. Calder, P.C. Very long-chain n-3 fatty acids and human health: Fact, fiction and the future. Proc. Nutr. Soc. 2018, 77, 52-72. [CrossRef] [PubMed]

12. Ahlgren, G.; Gustafsson, I.B.; Boberg, M. Fatty acid content and chemical composition of freshwater microalgae. J. Phycol. 1992, 28, 37-50. [CrossRef]

13. Davis, B.C.; Kris-Etherton, P.M. Achieving optimal essential fatty acid status in vegetarians: Current knowledge and practical implications. Am. J. Clin. Nutr. 2003, 78, 640S-646S. [CrossRef] [PubMed]

14. Stark, A.H.; Crawford, M.A.; Reifen, R. Update on alpha-linolenic acid. Nutr. Rev. 2008, 66, 326-332. [CrossRef] [PubMed]

15. Kang, X.; Bai, Y.; Sun, G.; Huang, Y.; Chen, Q.; Han, R.; Li, G.; Li, F. Molecular cloning, characterization, and expression analysis of chicken $\Delta-6$ desaturase. Asian-Australas. J. Anim. Sci. 2010, 23, 116-121. [CrossRef]

16. Uttaro, A.D. Biosynthesis of polyunsaturated fatty acids in lower eukaryotes. IUBMB Life 2006, 58, 563-571. [CrossRef] [PubMed]

17. Zhou, X.-R.; Green, A.G.; Singh, S.P. Caenorhabditis elegans $\Delta 12$-desaturase FAT-2 is a bifunctional desaturase able to desaturate a diverse range of fatty acid substrates at the $\Delta 12$ and $\Delta 15$ positions. J. Biol. Chem. 2011, 286, 43644-43650. [CrossRef] [PubMed]

18. Harwood, J.L. Recent advances in the biosynthesis of plant fatty acids. Biochim. Biophys. Acta 1996, 1301, 7-56. [CrossRef]

19. Sayanova, O.V.; Napier, J.A. Eicosapentaenoic acid: Biosynthetic routes and the potential for synthesis in transgenic plants. Phytochemistry 2004, 65, 147-158. [CrossRef]

20. Ward, O.P.; Singh, A. Omega-3/6 fatty acids: Alternative sources of production. Process Biochem. 2005, 40, 3627-5652. [CrossRef]

21. Ruiz-Lopez, N.; Sayanova, O.; Napier, J.A.; Haslam, R.P. Metabolic engineering of the omega-3 long chain polyunsaturated fatty acid biosynthetic pathway into transgenic plants. J. Exp. Bot. 2012, 63, 2397-2410. [CrossRef] [PubMed]

22. Gladyshev, M.I.; Arts, M.T.; Sushchik, N.N. Preliminary estimates of the export of omega-3 highly unsaturated fatty acids (EPA+DHA) from aquatic to terrestrial ecosystems. In Lipids in Aquatic Ecosystems; Arts, M.T., Kainz, M., Brett, M.T., Eds.; Springer: New York, NY, USA, 2009; pp. 179-209.

23. Sterner, R.W.; Schulz, K.L. Zooplankton nutrition: Recent progress and a reality check. Aquat. Ecol. 1998, 32, 261-279. [CrossRef]

24. Ahlgren, G.; Lundstedt, L.; Brett, M.; Forsberg, C. Lipid composition and food quality of some freshwater phytoplankton for cladoceran zooplankters. J. Plankton Res. 1990, 12, 809-818. [CrossRef]

25. Muller-Navarra, D.C. Biochemical versus mineral limitation in Daphnia. Limnol. Oceanogr. 1995, 40, 1209-1214. [CrossRef]

26. Gulati, R.D.; DeMott, W.R. The role of food quality for zooplankton: Remarks on the state-of-the-art, perspectives and priorities. Freshw. Biol. 1997, 38, 753-768. [CrossRef]

27. Wacker, A.; Becher, P.; Von Elert, E. Food quality effects of unsaturated fatty acids on larvae of the zebra mussel Dreissena polymorpha. Limnol. Oceanogr. 2002, 47, 1242-1248. [CrossRef]

28. Chu, F.L.E.; Lund, E.D.; Podbesek, J.A. Quantitative significance of n-3 essential fatty acid contribution by heterotrophic protists in marine pelagic food webs. Mar. Ecol. Prog. Ser. 2008, 354, 85-95. [CrossRef]

29. Martin-Creuzburg, D.; Wacker, A.; Basena, T. Interactions between limiting nutrients: Consequences for somatic and population growth of Daphnia magna. Limnol. Oceanogr. 2010, 55, 2597-2607. [CrossRef]

30. Peltomaa, E.T.; Aalto, S.L.; Vuorio, K.M.; Taipale, S.J. The Importance of phytoplankton biomolecule availability for secondary production. Front. Ecol. Evol. 2017, 5, 128. [CrossRef]

31. Taipale, S.; Strandberg, U.; Peltomaa, E.; Galloway, A.W.E.; Ojala, A.; Brett, M.T. Fatty acid composition as biomarkers of freshwater microalgae: Analysis of 37 strains of microalgae in 22 genera and in seven classes. Aquat. Microb. Ecol. 2013, 71, 165-178. [CrossRef]

32. Petkov, G.; Garcia, G. Which are fatty acids of the green alga Chlorella. Biochem. Syst. Ecol. 2007, 35, $281-285$. [CrossRef]

33. Iliev, I.; Petkov, G.; Lukavsky, J.; Furnadzhieva, S.; Andreeva, R. Do cyanobacterial lipids contain fatty acids longer than 18 carbon atoms. Z. Naturforsch. C 2011, 66, 267-276. [CrossRef] [PubMed]

34. Weers, P.M.M.; Gulati, R.D. Growth and reproduction of Daphnia galeata response to changes in fatty acids, phosphorus, and nitrogen in Chlamydomonas reinhardtii. Limnol. Oceanogr. 1997, 42, 1584-1589. [CrossRef] 
35. Nanton, D.A.; Castell, J.D. The effects of dietary fatty acids on the fatty acid composition of the harpacticoid copepod, Tisbe sp., for use a live food for marine fish larvae. Aquaculture 1998, 163, 251-261. [CrossRef]

36. Wacker, A.; Von Elert, E. Polyunsaturated fatty acids: Evidence for non-substitutable biochemical resources in Daphnia galeata. Ecology 2001, 82, 2507-2520. [CrossRef]

37. Sushchik, N.N.; Gladyshev, M.I.; Kalachova, G.S.; Kravchuk, E.S.; Dubovskaya, O.P.; Ivanova, E.A. Particulate fatty acids in two small Siberian reservoirs dominated by different groups of phytoplankton. Freshw. Biol. 2003, 48, 394-403. [CrossRef]

38. Brown, M.R.; Jeffrey, S.W.; Volkman, J.K.; Dunstan, G.A. Nutritional properties of microalgae for mariculture. Aquaculture 1997, 151, 315-331. [CrossRef]

39. Chen, X.; Wakeham, S.G.; Fisher, N.S. Influence of iron on fatty acid and sterol composition of marine phytoplankton and copepod consumers. Limnol. Oceanogr. 2011, 56, 716-724. [CrossRef]

40. Claustre, H.; Marty, J.C.; Cassiani, L.; Dagaut, J. Fatty acid dynamics in phytoplankton and microzooplankton communities during a spring bloom in the coastal Ligurian Sea: Ecological implications. Mar. Microb. Food Webs 1989, 3, 51-66.

41. Sushchik, N.N.; Gladyshev, M.I.; Makhutova, O.N.; Kalachova, G.S.; Kravchuk, E.S.; Ivanova, E.A. Associating particulate essential fatty acids of the $\omega 3$ family with phytoplankton species composition in a Siberian reservoir. Freshw. Biol. 2004, 49, 1206-1219. [CrossRef]

42. Sushchik, N.N.; Gladyshev, M.I.; Ivanova, E.A.; Kravchuk, E.S. Seasonal distribution and fatty acid composition of littoral microalgae in the Yenisei River. J. Appl. Phycol. 2010, 22, 11-24. [CrossRef]

43. Gladyshev, M.I.; Sushchik, N.N.; Kolmakova, A.A.; Kalachova, G.S.; Kravchuk, E.S.; Ivanova, E.A.; Makhutova, O.N. Seasonal correlations of elemental and w3 PUFA composition of seston and dominant phytoplankton species in a eutrophic Siberian Reservoir. Aquat. Ecol. 2007, 41, 9-23. [CrossRef]

44. Ahlgren, G.; Sonesten, L.; Boberg, M.; Gustafsson, I.-B. Fatty acid content of some freshwater fish in lakes of different trophic levels-A bottom-up effect? Ecol. Freshw. Fish 1996, 5, 15-27. [CrossRef]

45. Taipale, S.J.; Vuorioc, K.; Strandberg, U.; Kahilainen, K.K.; Jarvinen, M.; Hiltunen, M.; Peltomaa, E.; Kankaala, P. Lake eutrophication and brownification downgrade availability and transfer of essential fatty acids for human consumption. Environ. Int. 2016, 96, 156-166. [CrossRef] [PubMed]

46. Muller-Navarra, D.C.; Brett, M.T.; Park, S.; Chandra, S.; Ballantyne, A.P.; Zorita, E.; Goldman, C.R. Unsaturated fatty acid content in seston and tropho-dynamic coupling in lakes. Nature 2004, 427, 69-72. [CrossRef] [PubMed]

47. Razavi, N.R.; Arts, M.T.; Qua, M.; Jin, B.; Rend, W.; Wang, Y.; Campbell, L.M. Effect of eutrophication on mercury, selenium, and essential fatty acids in Bighead Carp (Hypophthalmichthys nobilis) from reservoirs of eastern China. Sci. Total Environ. 2014, 499, 36-46. [CrossRef]

48. Smith, V.H. Nutrient dependence of primary productivity in lakes. Limnol. Oceanogr. 1979, 24, 1051-1064. [CrossRef]

49. Gladyshev, M.I. Quality and quantity of biological production in water bodies with different concentration of phosphorus: Case study of Eurasian perch. Dokl. Biochem. Biophys. 2018, 478, 1-3. [CrossRef]

50. Sushchik, N.N.; Gladyshev, M.I.; Makhutova, O.N.; Kravchuk, E.S.; Dubovskaya, O.P.; Kalacheva, G.S. Seasonal transfer of the pool of the essential eicosapentaenoic acid along the pelagic trophic chain of a eutrophic reservoir. Dokl. Biol. Sci. 2008, 422, 355-356. [CrossRef]

51. Khozin-Goldberg, I.; Cohen, Z. The effect of phosphate starvation on the lipid and fatty acid composition of the fresh water eustigmatophyte Monodus subterraneus. Phytochemistry 2006, 67, 696-701. [CrossRef]

52. Twining, C.W.; Brenna, J.T.; Hairston, N.G., Jr.; Flecker, A.S. Highly unsaturated fatty acids in nature: What we know and what we need to learn. Oikos 2015, 125, 749-760. [CrossRef]

53. Hixson, S.M.; Sharma, B.; Kainz, M.J.; Wacker, A.; Arts, M.T. Production, distribution, and abundance of long-chain omega-3 polyunsaturated fatty acids: A fundamental dichotomy between freshwater and terrestrial ecosystems. Environ. Rev. 2015, 23, 414-424. [CrossRef]

54. Stanley-Samuelson, D.W.; Jurenka, R.A.; Cripps, C.; Blomquist, G.J.; de Renobales, M. Fatty acids in insects: Composition, metabolism, and biological significance. Arch. Insect Biochem. Physiol. 1988, 9, 1-33. [CrossRef]

55. Buckner, J.S.; Hagen, M.M. Triacylglycerol and phospholipid fatty acids of the silverleaf whitefly: Composition and biosynthesis. Arch. Insect Biochem. Physiol. 2003, 53, 66-79. [CrossRef]

56. Wang, Y.; Lin, D.S.; Bolewicz, L.; Connor, W.E. The predominance of polyunsaturated fatty acids in the butterfly Morpho peleides before and after metamorphosis. J. Lipid Res. 2006, 47, 530-536. [CrossRef] 
57. Rumpold, B.A.; Schluter, O.K. Nutritional composition and safety aspects of edible insects. Mol. Nutr. Food Res. 2013, 57, 802-823. [CrossRef]

58. Barroso, F.G.; de Haro, C.; Sanchez-Muros, M.J.; Venegas, E.; Martinez-Sanchez, A.; Perez-Ban, C. The potential of various insect species for use as food for fish. Aquaculture 2014, 422, 193-201. [CrossRef]

59. Sanchez-Muros, M.-J.; Barroso, F.G.; Manzano-Agugliaro, F. Insect meal as renewable source of food for animal feeding: A review. J. Clean. Prod. 2014, 65, 16-27. [CrossRef]

60. Stanley, D.; Kim, Y. Eicosanoid signaling in insects: From discovery to plant protection. Crit. Rev. Plant Sci. 2014, 33, 20-63. [CrossRef]

61. Sushchik, N.N.; Yurchenko, Y.A.; Gladyshev, M.I.; Belevich, O.E.; Kalachova, G.S.; Kolmakova, A.A. Comparison of fatty acid contents and composition in major lipid classes of larvae and adults of mosquitoes (Diptera: Culicidae) from a steppe region. Insect Sci. 2013, 20, 585-600. [CrossRef]

62. Borisova, E.V.; Makhutova, O.N.; Gladyshev, M.I.; Sushchik, N.N. Fluxes of biomass and essential polyunsaturated fatty acids from water to land via chironomid emergence from a mountain lake. Contemp. Probl. Ecol. 2016, 9, 446-457. [CrossRef]

63. Makhutova, O.N.; Borisova, E.V.; Shulepina, S.P.; Kolmakova, A.A.; Sushchik, N.N. Fatty acid composition and content in chironomid species at various life stages dominating in a saline Siberian lake. Contemp. Probl. Ecol. 2017, 10, 230-239. [CrossRef]

64. Popova, O.N.; Haritonov, A.Y.; Sushchik, N.N.; Makhutova, O.N.; Kalachova, G.S.; Kolmakova, A.A.; Gladyshev, M.I. Export of aquatic productivity, including highly unsaturated fatty acids, to terrestrial ecosystems via Odonata. Sci. Total Environ. 2017, 581, 40-48. [CrossRef] [PubMed]

65. Politi, L.; Rotstein, N.; Carri, N. Effects of docosahexaenoic acid on retinal development: Cellular and molecular aspects. Lipids 2001, 36, 927-935. [CrossRef] [PubMed]

66. Bazan, N.G. Cellular and molecular events mediated by docosahexaenoic acid-derived neuroprotectin D1 signaling in photoreceptor cell survival and brain protection. Prostaglandins Leukot. Essent. Fatty Acids 2009, 81, 205-211. [CrossRef]

67. Ziegler, A.B.; Ménagé, C.; Grégoire, S.; Garcia, T.; Ferveur, J.-F.; Bretillon, L.; Grosjean, Y. Lack of dietary polyunsaturated fatty acids causes synapse dysfunction in the Drosophila visual system. PLoS ONE 2015, 10, e0135353. [CrossRef] [PubMed]

68. Sushchik, N.N.; Popova, O.N.; Makhutova, O.N.; Gladyshev, M.I. Fatty acid composition of odonate's eyes. Dokl. Biochem. Biophys. 2017, 475, 280-282. [CrossRef] [PubMed]

69. Sampedro, L.; Jeannotte, R.; Whalen, J.K. Trophic transfer of fatty acids from gut microbiota to the earthworm Lumbricus terrestris L. Soil Biol. Biochem. 2006, 38, 2188-2198. [CrossRef]

70. Gladyshev, M.I.; Sushchik, N.N.; Gubanenko, G.A.; Makhutova, O.N.; Kalachova, G.S.; Rechkina, E.A.; Malyshevskaya, K.K. Effect of the way of cooking on contents of essential polyunsaturated fatty acids in filets of zander. Czech. J. Food Sci. 2014, 32, 226-231. [CrossRef]

71. Manukovsky, N.S.; Kovalev, V.S.; Gribovskaya, I.V. Two-stage biohumus production from inedible potato biomass. Bioresour. Technol. 2001, 78, 273-275. [CrossRef]

72. Menzel, R.; von Chrzanowski, H.; Tonat, T.; van Riswyck, K.; Schliesser, P.; Ruess, L. Presence or absence? Primary structure, regioselectivity and evolution of Delta 12/omega 3 fatty acid desaturases in nematodes. Biochim. Biophys. Acta Mol. Cell Biol. Lipids 2019, 1864, 1194-1205. [CrossRef] [PubMed]

73. Kouba, M.; Mourot, J. A review of nutritional effects on fat composition of animal products with special emphasis on n-3 polyunsaturated fatty acids. Biochimie 2011, 93, 13-17. [CrossRef]

74. Infante, J.P.; Kirwan, R.C.; Brenna, J.T. High levels of docosahexaenoic acid (22:6n-3)-containing phospholipids in high-frequency contraction muscles of hummingbirds and rattlesnakes. Comp. Biochem. Physiol. Part B 2001, 130, 291-298. [CrossRef]

75. Geiser, F.; McAllan, B.M.; Kenagy, G.J.; Hiebert, S.M. Photoperiod affects daily torpor and tissue fatty acid composition in deer mice. Naturwissenschaften 2007, 94, 319-325. [CrossRef] [PubMed]

76. Klaiman, J.M.; Price, E.R.; Guglielmo, C.G. Fatty acid composition of pectoralis muscle membrane, intramuscular fat stores and adipose tissue of migrant and wintering white-throated sparrows (Zonotrichia albicollis). J. Exp. Biol. 2009, 212, 3865-3872. [CrossRef]

77. Stawski, C.; Valencak, T.G.; Ruf, T.; Sadowska, E.T.; Dheyongera, G.; Rudolf, A.; Maiti, U.; Koteja, P. Effect of selection for high activity-related metabolism on membrane phospholipid fatty acid composition in bank voles. Physiol. Biochem. Zool. 2015, 88, 668-679. [CrossRef] 
78. Fritz, K.A.; Kirschman, L.J.; McCay, S.D.; Trushenski, J.T.; Warne, R.W.; Whiles, M.R. Subsidies of essential nutrients from aquatic environments correlate with immune function in terrestrial consumers. Freshw. Sci. 2017, 36, 893-900. [CrossRef]

79. Twining, C.W.; Lawrence, P.; Winkler, D.W.; Flecker, A.S.; Brenna, J.T. Conversion efficiency of $\alpha$-linolenic acid to omega-3 highly unsaturated fatty acids in aerial insectivore chicks. J. Exp. Biol. 2018, 221, jeb165373. [CrossRef] [PubMed]

80. Robert, S.S. Production of eicosapentaenoic and docosahexaenoic acid-containing oils in transgenic land plants for human and aquaculture nutrition. Mar. Biotechnol. 2006, 8, 103-109. [CrossRef]

81. Adkins, Y.; Kelley, D.S. Mechanisms underlying the cardioprotective effects of omega-3 polyunsaturated fatty acids. J. Nutr. Biochem. 2010, 2, 781-792. [CrossRef]

82. Gladyshev, M.I.; Sushchik, N.N.; Makhutova, O.N. Production of EPA and DHA in aquatic ecosystems and their transfer to the land. Prostaglandins Other Lipid Mediat. 2013, 107, 117-126. [CrossRef] [PubMed]

83. Gladyshev, M.I.; Makhutova, O.N.; Gubanenko, G.A.; Rechkina, E.A.; Kalachova, G.S.; Sushchik, N.N. Livers of terrestrial production animals as a source of long-chain polyunsaturated fatty acids for humans: An alternative to fish? Eur. J. Lipid Sci. Technol. 2015, 117, 1417-1421. [CrossRef]

84. Cladis, D.P.; Kleiner, A.C.; Freiser, H.H.; Santerre, C.R. Fatty acid profiles of commercially available finfish fillets in the United States. Lipids 2014, 49, 1005-1018. [CrossRef] [PubMed]

85. Gladyshev, M.I.; Glushchenko, L.A.; Makhutova, O.N.; Rudchenko, A.E.; Shulepina, S.P.; Dubovskaya, O.P.; Zuev, I.V.; Kolmakov, V.I.; Sushchik, N.N. Comparative analysis of content of omega-3 polyunsaturated fatty acids in food and muscle tissue of fish from aquaculture and natural habitats. Contemp. Probl. Ecol. 2018, 11, 297-308. [CrossRef]

86. Teoh, C.Y.; Ng, W.K. The implications of substituting dietary fish oilwith vegetable oils on the growth performance, fillet fatty acid profile and modulation of the fatty acid elongase, desaturase and oxidation activities of red hybrid tilapia, Oreochromis sp. Aquaculture 2016, 465, 311-322. [CrossRef]

87. Harris, W.S.; Mozaffarian, D.; Lefevre, M.; Toner, C.D.; Colombo, J.; Cunnane, S.C.; Holden, J.M.; Klurfeld, D.M.; Morris, M.C.; Whelan, J. Towards establishing dietary reference intakes for eicosapentaenoic and docosahexaenoic acids. J. Nutr. 2009, 139, 804S-819S. [CrossRef] [PubMed]

88. Nagasaka, R.; Gagnon, C.; Swist, E.; Rondeau, I.; Massarelli, I.; Cheung, W.; Ratnayake, W.M.N. EPA and DHA status of South Asian and white Canadians living in the National Capital Region of Canada. Lipids 2014, 49, 1057-1069. [CrossRef]

89. Gladyshev, M.I.; Popova, O.N.; Makhutova, O.N.; Zinchenko, T.D.; Golovatyuk, L.V.; Yurchenko, Y.A.; Kalachova, G.S.; Krylov, A.V.; Sushchik, N.N. Comparison of fatty acid compositions in birds feeding in aquatic and terrestrial ecosystems. Contemp. Probl. Ecol. 2016, 9, 503-513. [CrossRef]

90. Burdge, G.C.; Henry, C.J. Omega-3 Polyunsaturated Fatty Acid Metabolism in Vegetarians. In Polyunsaturated Fatty Acid Metabolism; Burdge, G.C., Ed.; Elsevier Inc.: Amsterdam, The Netherland; AOCS Press: Urbana, IL, USA, 2018; pp. 193-204.

91. Burdge, G.C. Is essential fatty acid interconversion an important source of PUFA in humans? Br. J. Nutr. 2019, 121, 615-624. [CrossRef]

92. Kothapalli, K.S.; Ye, K.; Gadgil, M.S.; Carlson, S.E.; O’Brien, K.O.; Zhang, J.Y.; Park, H.G.; Ojukwu, K.; Zou, J.; Hyon, S.S.; et al. Positive selection on a regulatory insertion-deletion polymorphism in FADS2 influences apparent endogenous synthesis of arachidonic acid. Mol. Biol. Evol. 2016, 33, 1726-1739. [CrossRef]

93. Buckley, M.T.; Racimo, F.; Allentoft, M.E.; Jensen, M.K.; Jonsson, A.; Huang, H.; Hormozdiari, F.; Sikora, M.; Marnetto, D.; Eskin, E.; et al. Selection in Europeans on fatty acid desaturases associated with dietary changes. Mol. Biol. Evol. 2017, 34, 1307-1318. [CrossRef] [PubMed]

94. Chilton, F.H.; Dutta, R.; Reynolds, L.M.; Sergeant, S.; Mathias, R.A.; Seeds, M.C. Precision nutrition and omega-3 polyunsaturated fatty acids: A case for personalized supplementation approaches for the prevention and management of human diseases. Nutrients 2017, 9, 1165. [CrossRef] [PubMed]

95. Sprague, M.; Dick, J.R.; Tocher, D.R. Impact of sustainable feeds on omega-3 long-chain fatty acid levels in farmed Atlantic salmon, 2006-2015. Sci. Rep. 2016, 6, 21892. [CrossRef] [PubMed]

96. Estevez, M.; Ventanas, S.; Cava, R. Oxidation of lipids and proteins in frankfurters with different fatty acid compositions and tocopherol and phenolic contents. Food Chem. 2007, 100, 55-63. [CrossRef]

97. Ruiz-Rodriguez, A.; Marin, F.R.; Ocana, A.; Soler-Rivas, C. Effect of domestic processing on bioactive compounds. Phytochem. Rev. 2008, 7, 345-384. [CrossRef] 
98. Ganhão, R.; Estévez, M.; Armenteros, M.; Morcuende, D. Mediterranean berries as inhibitors of lipid oxidation in porcine burger patties subjected to cooking and chilled storage. J. Integr. Agric. 2013, 12, 1982-1992. [CrossRef]

99. Ohshima, T.; Shozen, K.; Usio, H.; Koizumi, C. Effects of grilling on formation of cholesterol oxides in seafood products rich in polyunsaturated fatty acids. LWT-Food Sci. Technol. 1996, 29, 94-99. [CrossRef]

100. Tarley, C.R.T.; Visentainer, J.V.; Matsushita, M.; de Souza, N.E. Proximate composition, cholesterol and fatty acids profile of canned sardines (Sardinella brasiliensis) in soybean oil and tomato sauce. Food Chem. 2004, 88, 1-6. [CrossRef]

101. Sampaio, G.R.; Bastos, D.H.M.; Soares, R.A.M.; Queiroz, Y.S.; Torres, E.A.F.S. Fatty acids and cholesterol oxidation in salted and dried shrimp. Food Chem. 2006, 95, 344-351. [CrossRef]

102. De Castro, F.A.F.; Sant'Ana, H.M.P.; Campos, F.M.; Costa, N.M.B.; Silva, M.T.C.; Salaro, A.L.; Franceschini, S.D.C.C. Fatty acid composition of three freshwater fishes under different storage and cooking processes. Food Chem. 2007, 103, 1080-1090. [CrossRef]

103. Saldanha, T.; Bragagnolo, N. Relation between types of packaging, frozen storage and grilling on cholesterol and fatty acids oxidation in Atlantic hake fillets (Merluccius hubbsi). Food Chem. 2008, 106, 619-627. [CrossRef]

104. Weber, J.; Bochi, V.C.; Ribeiro, C.P.; Victorio, A.D.M.; Emanuelli, T. Effect of different cooking methods on the oxidation, proximate and fatty acid composition of silver catfish (Rhamdia quelen) fillets. Food Chem. 2008, 106, 140-146. [CrossRef]

105. Mnari, A.B.; Jrah, H.H.; Dhibi, M.; Bouhlel, I.; Hammami, M.; Chaouch, A. Nutritional fatty acid quality of raw and cooked farmed and wild sea bream (Sparus aurata). J. Agric. Food Chem. 2010, 58, 507-512. [CrossRef] [PubMed]

106. Zotos, A.; Kotaras, A.; Mikras, E. Effect of baking of sardine (Sardina pilchardus) and frying of anchovy (Engraulis encrasicholus) in olive and sunflower oil on their quality. Food Sci. Technol. Int. 2013, 19, 11-23. [CrossRef] [PubMed]

107. Sampels, S.; Zajíc, T.; Mráz, J. Effects of frying fat and preparation on carp (Cyprinus carpio) fillet lipid composition and oxidation. Czech J. Food Sci. 2014, 32, 493-502. [CrossRef]

108. Ferreira, F.S.; Sampaio, G.R.; Keller, L.M.; Sawaya, A.C.H.F.; Chavez, D.W.H.; Torres, E.A.F.S.; Saldanha, T. Impact of air frying on cholesterol and fatty acids oxidation in sardines: Protective effects of aromatic herbs. J. Food Sci. 2017, 82, 2823-2831. [CrossRef] [PubMed]

109. Shalini, R.; Jeya Shakila, R.; Palani Kumar, M.; Jeyasekaran, G. Changes in the pattern of health beneficial omega 3 fatty acids during processing of sardine fish curry. Indian J. Fish. 2017, 64, 260-263. [CrossRef]

110. Dong, X.P.; Li, D.Y.; Huang, Y.; Wu, Q.; Liu, W.T.; Qin, L.; Zhou, D.Y.; Prakash, S.; Yu, C.X. Nutritional value and flavor of turbot (Scophthalmus maximus) muscle as affected by cooking methods. Int. J. Food Prop. 2018, 21, 1972-1985. [CrossRef]

111. Chaula, D.; Laswai, H.; Chove, B.; Dalsgaard, A.; Mdegela, R.; Hyldig, G. Fatty acid profiles and lipid oxidation status of sun dried, deep fried, and smoked sardine (Rastrineobola argentea) from Lake Victoria, Tanzania. J. Aquat. Food Prod. Technol. 2019, 2, 165-176. [CrossRef]

112. Candela, M.; Astiasaran, I.; Bello, J. Deep-fat frying modifies high-fat fish lipid fraction. J. Agric. Food Chem. 1998, 46, 2793-2796. [CrossRef]

113. Echarte, M.; Zulet, M.A.; Astiasaran, I. Oxidation process affecting fatty acids and cholesterol in fried and roasted salmon. J. Agric. Food Chem. 2001, 49, 5662-5667. [CrossRef] [PubMed]

114. Sioen, I.; Haak, L.; Raes, K.; Hermans, C.; De Henauw, S.; De Smet, S.; Van Camp, J. Effects of pan-frying in margarine and olive oil on the fatty acid composition of cod and salmon. Food Chem. 2006, 98, 609-617. [CrossRef]

115. Stolyhwo, A.; Kolodziejska, I.; Sikorski, Z.E. Long chain polyunsaturated fatty acids in smoked Atlantic mackerel and Baltic sprats. Food Chem. 2006, 94, 589-595. [CrossRef]

116. Gladyshev, M.I.; Sushchik, N.N.; Gubanenko, G.A.; Demirchieva, S.M.; Kalachova, G.S. Effect of way of cooking on content of essential polyunsaturated fatty acids in muscle tissue of humpback salmon (Oncorhynchus gorbuscha). Food Chem. 2006, 96, 446-451. [CrossRef]

117. Gladyshev, M.I.; Sushchik, N.N.; Gubanenko, G.A.; Demirchieva, S.M.; Kalachova, G.S. Effect of boiling and frying on the content of essential polyunsaturated fatty acids in muscle tissue of four fish species. Food Chem. 2007, 101, 1694-1700. [CrossRef] 
118. Gladyshev, M.I.; Sushchik, N.N.; Makhutova, O.N.; Kalachova, G.S. Content of essential polyunsaturated fatty acids in three canned fish species. Int. J. Food Sci. Nutr. 2009, 60, 224-230. [CrossRef] [PubMed]

119. Haak, L.; Sioen, I.; Raes, K.; Van Camp, J.; De Smet, S. Effect of pan-frying in different culinary fats on the fatty acid profile of pork. Food Chem. 2007, 102, 857-864. [CrossRef]

120. Yanar, Y.; Büyükçapar, H.M.; Yanar, M.; Göcer, M. Effect of carotenoids from red pepper and marigold flower on pigmentation, sensory properties and fatty acid composition of rainbow trout. Food Chem. 2007, 100, 326-330. [CrossRef]

121. Ansorena, D.; Guembe, A.; Mendizabal, T.; Astiasaran, I. Effect of fish and oil nature on frying process and nutritional product quality. J. Food Sci. 2010, 75, H62-H67. [CrossRef] [PubMed]

122. Neff, M.R.; Bhavsar, S.P.; Braekevelt, E.; Arts, M.T. Effects of different cooking methods on fatty acid profiles in four freshwater fishes from the Laurentian Great Lakes region. Food Chem. 2014, 164, 544-550. [CrossRef] [PubMed]

123. Cheung, L.K.Y.; Tomita, H.; Takemori, T. Mechanisms of docosahexaenoic and eicosapentaenoic acid loss from Pacific saury and comparison of their retention rates after various cooking methods. J. Food Sci. 2016, 81, C1899-C1907. [CrossRef] [PubMed]

124. Kronberg, S.L.; Scholljegerdes, E.J.; Maddock, R.J.; Barcelo-Coblijn, G.; Murphy, E.J. Rump and shoulder muscles from grass and linseed fed cattle as important sources of n-3 fatty acids for beef consumers. Eur. J. Lipid Sci. Technol. 2017, 119, 1600390. [CrossRef]

125. Litzow, M.A.; Bailey, K.M.; Prahl, F.G.; Heintz, R. Climate regime shifts and reorganization of fish communities: The essential fatty acid limitation hypothesis. Mar. Ecol. Prog. Ser. 2006, 315, 1-11. [CrossRef]

126. Wells, M.L.; Potin, P.; Craigie, J.S.; Raven, J.A.; Merchant, S.S.; Helliwell, K.E.; Smith, A.G.; Camire, M.E.; Brawley, S.H. Algae as nutritional and functional food sources: Revisiting our understanding. J. Appl. Phycol. 2017, 29, 949-982. [CrossRef] [PubMed]

127. Woods, V.B.; Fearon, A.M. Dietary sources of unsaturated fatty acids for animals and their transfer into meat, milk and eggs: A review. Livest. Sci. 2009, 126, 1-20. [CrossRef]

128. Turchini, G.M.; Hermon, K.M.; Francis, D.S. Fatty acids and beyond: Fillet nutritional characterisation of rainbow trout (Oncorhynchus mykiss) fed different dietary oil sources. Aquaculture 2018, 491, 391-397. [CrossRef]

129. Gladyshev, M.I.; Sushchik, N.N.; Tolomeev, A.P.; Dgebuadze, Y.Y. Meta-analysis of factors associated with omega-3 fatty acid contents of wild fish. Rev. Fish. Biol. Fish. 2018, 28, 277-299. [CrossRef]

130. Mairesse, G.; Thomas, M.; Gardeur, J.-N.; Brun-Bellut, J. Effects of geographic source rearing system, and season on the nutritional quality of wild and farmed Perca fluviatilis. Lipids 2006, 41, 221-229. [CrossRef]

131. Kiessling, A.; Pickova, J.; Johansson, L.; Esgerd, T.; Storebakken, T.; Kiessling, K.-H. Changes in fatty acid composition in muscle and adipose tissue of farmed rainbow trout (Oncorhynchus mykiss) in relation to ration and age. Food Chem. 2001, 73, 271-284. [CrossRef]

132. Benedito-Palos, L.; Calduch-Giner, J.A.; Ballester-Lozano, G.F.; Pérez-Sánchez, J. Effect of ration size on fillet fatty acid composition, phospholipid allostasis and mRNA expression patterns of lipid regulatory genes in gilthead sea bream (Sparus aurata). Br. J. Nutr. 2013, 109, 1175-1187. [CrossRef]

133. Moths, M.D.; Dellinger, J.A.; Holub, B.; Ripley, M.P.; McGraw, J.E.; Kinnunen, R.E. Omega-3 fatty acids in fish from the Laurentian Great Lakes tribal fisheries. Hum. Ecol. Risk Assess. 2013, 19, 1628-1643. [CrossRef]

134. Huynh, M.D.; Kitts, D.D. Evaluating nutritional quality of pacific fish species from fatty acid signatures. Food Chem. 2009, 114, 912-918. [CrossRef]

135. Joordens, J.C.A.; Kuipers, R.S.; Wanink, J.H.; Muskiet, F.A.J. A fish is not a fish: Patterns in fatty acid composition of aquatic food may have had implications for hominin evolution. J. Hum. Evol. 2014, 77, 107-116. [CrossRef] [PubMed]

136. Anishchenko, O.V.; Sushchik, N.N.; Makhutova, O.N.; Kalachova, G.S.; Gribovskaya, I.V.; Morgun, V.N.; Gladyshev, M.I. Benefit-risk ratio of canned pacific saury (Cololabis saira) intake: Essential fatty acids vs. heavy metals. Food Chem. Toxicol. 2017, 101, 8-14. [CrossRef] [PubMed]

137. Larsen, D.; Quek, S.Y.; Eyres, L. Effect of cooking method on the fatty acid profile of New Zealand King Salmon (Oncorhynchus tshawytscha). Food Chem. 2010, 119, 785-790. [CrossRef]

138. Simon, S.J.G.B.; Sancho, R.A.S.; Lima, F.A.; Cabral, C.C.V.Q.; Souza, T.M.; Bragagnolo, N.; Lira, G.M. Interaction between soybean oil and the lipid fraction of fried pitu prawn. LWT-Food Sci. Technol. 2012, 48, 120-126. [CrossRef] 
139. Amira, M.B.; Hanene, J.H.; Madiha, D.; Imen, B.; Mohamed, H.; Abdelhamid, C. Effects of frying on the fatty acid composition in farmed and wild gilthead sea bream (Sparus aurata). Int. J. Food Sci. Technol. 2010, 45, 113-123. [CrossRef]

140. Kouba, M.; Benatmane, F.; Blochet, J.E.; Mourot, J. Effect of a linseed diet on lipid oxidation, fatty acid composition of muscle, perirenal fat, and raw and cooked rabbit meat. Meat Sci. 2008, 80, 829-834. [CrossRef] 